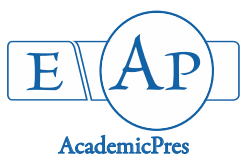

Olisa BS et al. (2021)

Notulae Scientia Biologicae

Volume 13, Issue 4, Article number 10738

DOI: $10.15835 / \mathrm{nsb} 13410738$

Research Article

\title{
Differential response of commercial hybrid and open pollinated maize seeds to mechanical damage during seed processing
}

\author{
Babafemi S. OLISA ${ }^{1 *}$, Femi E. AWOSANMI², Michael S. AKINROPO ${ }^{3}$, \\ Philip O. OJO ${ }^{1}$, Khalid ISHIAK ${ }^{1}$, Abdul DANLAMI ${ }^{1}$, \\ Nwakaku J. EGBO ${ }^{1}$, Christiana U. OKEKE ${ }^{1}$
}

\author{
${ }^{I}$ National Agricultural Seeds Council, Central Seed Testing Laboratory, Km 29 Abuja Lokoja Express way, P.M.B 716 Garki, \\ Nigeria; zionolisa3@gmail.com (*correspondingauthor);dr.poojo@gmail.com; ishiakbio@gmail.com; aabduldanlami@gmail.com; \\ janenwakaku@yahoo.com; christine75.cu@gmail.com \\ ${ }^{2}$ Obafemi Awolowo University, Faculty of Agriculture, Department of Crop Production and Protection, Seed Science Laboratory, \\ Ile-Ife, Nigeria; femiawosanmi@oauife.edu.ng \\ ${ }^{3}$ Obafemi Awolowo University Nigeria, Faculty of Science, Department of Botany, Plant Physiology Units, Ile-Ife, \\ Nigeria;mickoseun@yahoo.com
}

\begin{abstract}
Hybrids and open pollinated varieties (OPVs) are two commercial maize seed types cultivated in Nigeria. Information on their response to mechanical damage during processing is limited. This study is thus aimed at assessing the response of hybrids and OPVs of maize seeds to mechanical damage which would facilitate fabrication of processing facilities suitable for either of the maize types. Six maize varieties: three hybids ('New Kaduna', 'SDM-1', and 'JO-195') and three OPVs ('Sammaz 15', 'Sammaz 27' and 'Suwan-1stry') were used for the study. The seed samples were subjected to standard germination, seedling vigour analysis, accelerated ageing, conductivity and fast green tests. The result showed that all the hybrid seed varieties had more damaged seeds than their OPVs counterpart. Shoot length and root length were more affected than other parts of the seedling. There were differences in the magnitude of electrolyte leakage as well as in what time each seed type (hybrid or OPVs) passed through the phases with 'JO-195' having the highest rate of electrolyte leakage. Hybrid seeds had lower resistance to mechanical damage and poorer storability when compared with the OPVs. In the overall, for all the traits, 'Sammaz 15', the best among OPVs was more promising when compared with 'SDM-1' which was the best among hybrid varieties. Processing machine equipment and accessories that are suitable for hybrid seeds might be inappropriate for conditioning OPVs.

Keywords: deterioration; harvesting; germination; leachate; physiological; triphasic

Abbreviations: AAT: Normal seedlings from accelerated ageing test; ABN: Abnormal seedling (\%); ASHT: Shoot length of normal seedling from accelerated ageing test $(\mathrm{cm})$; ARTL: Root length of normal seedling from accelerated ageing test $(\mathrm{cm})$; COND: Amount of electrolyte leachate from conductivity test; DEAD: Number of dead seeds (\%); FEM: Percent field emergence; GPT: Normal seedling after final count from standard germination test; HSWT: Hundred seed weight (g); ISTGPCT: Normal seedling at first count from standard germination test (\%); ISTFEM: Normal seedling at first count from field emergence (\%); LIST: Length of first leaf $(\mathrm{cm})$; LCOEP: Length of Coleoptile $(\mathrm{cm})$; MESCO: Length of Mesocotyl $(\mathrm{cm})$; NDS:

Received: 07 Jun 2021. Received in revised form: 20 Nov 2021. Accepted: 25 Nov 2021. Published online: 09 Dec 2021.

From Volume 13, Issue 1, 2021, Notulae Scientia Biologicae journal uses article numbers in place of the traditional method of continuous pagination through the volume. The journal will continue to appear quarterly, as before, with four annual numbers.
\end{abstract}


Number of damaged seeds (\%); NOR: Number of roots; OPV: Open pollinated varieties; RTL: Root Length $(\mathrm{cm})$; SHT: Shoot Length $(\mathrm{cm})$

\section{Introduction}

Maize is one of the major crops in Nigeria. Hybrid and OPVs are two commercial maize seed types cultivated in Nigeria. Hybrid varieties are the first-generation offspring of a cross between inbred line parents, OPVs, and other populations used for commercial planting (Badu-Apraku et al., 2014). The open pollinated species of plants are typically categorized by their tendency to breed true to type when left to reproduce naturally (Bassett, 2019). The national average grain yield for OPVs and hybrid maize varieties was estimated at $1.2 \mathrm{mt} \mathrm{ha}{ }^{-1}$, and $5.5-10 \mathrm{mt} \mathrm{ha}^{-1}$ respectively (Umar et al., 2014). Despite this, OPVs are more cultivated when compared with hybrid maize seeds in Nigeria. From both commercial seed producers and farmers, several reasons account for this situation. Firstly, from producers' point of view, hybrid seed production is more capital intensive, only available where there is an established formal or commercial seed sector. The commercial seed sector, on the other hand, only invests in areas where purchasing power and actual demand for hybrid seeds are adequate to guarantee profitability. Likewise, in case of farmers, the reasons why they may not invest in hybrid seed include high cost of seed, lack of cash at planting time, non-availability of hybrid seeds at local shops, the need to also purchase fertilizer, small or no difference in yield when compared to some of the local varieties, lack of adaptation, poor storability and poor processing quality of commercially available hybrids (Pixley and Bänziger, 2001). Thus, these arguments have raised the question whether hybrid seeds have an advantage over OPV seeds in Nigerian situations.

The general consensus, from a technical point of view, is that seed processing which involves threshing cleaning, grading, and sometimes chemical dressing of the seed materials is aimed at raising the overall quality of the finished seeds in meeting the specific needs of the end users (Kumawat et al., 2017). Nevertheless, loss in seed quality during seed processing appears inevitable. Mechanical damage is caused by abrasions and impacts as the seeds pass through series of machines. This kind of damage is a serious problem in the commercial seed industry. The problem is as a result of inevitable consequence of mechanization. This is because mechanization facilitates timeliness in seed production and minimizes production cost (Ajayi et al., 2006). The impact of damage does not only depend on processing operations, but also on velocity of impact, seed structural features, seed variety, seed type, seed moisture content, stage of ripeness, fertilization level and unsuitable equipment adjustment (Shahbazi and Shahbazi, 2018).

Maize seeds being non chaffy in nature are susceptible to mechanical damage during seed processing (Desai, 2004). This predisposed the seeds to physical and physiological deterioration and ultimately loss of seed quality. However, information relating the comparative response of hybrid and OPVs to mechanical damage during processing is limited. The result of this study will not only provide vital information that can be used to design harvesting and other processing machines but also help to identify reasons for improving storage life of hybrid seeds. Therefore, the objectives of this study are to assess the response of hybrid and opv of maize seeds to mechanical damage during processing and to identify varieties that are tolerant to mechanical damage among the commercial seed types.

\section{Materials and Methods}

\section{Seed collection and planting material}

The study was conducted in Central Seeds Testing Laboratory of National Agricultural Seeds Council, Abuja, Nigeria. Seeds samples were collected from three commercial seed producers: Premier Seeds, Da-AllGreen Seeds and Maslaha Seeds in Nigeria. Three commercial hybrid seeds which include: 'New Kaduna', 
'SDM-1' and 'Jo-195'; and three OPVs which include 'Sammaz 27', 'Suwan-1-stry' and 'Sammaz 15' were used for this investigation (Table 1). Harvest moisture content for the seeds ranged between 10.0 to $13.0 \%$ for all the seeds. The seeds were harvested manually. Subsequent processing operations which include shelling and cleaning were done mechanically. None of the seeds were graded nor treated. Samples of processed seeds were collected at bagging stage. Tests results of unprocessed seeds were used as the reference point for estimating tolerance of seed to damage during mechanical processing operations. The experiments were carried out both in the laboratory and on the field using Randomized Complete Block Design. The experiments were replicated three times under both conditions.

Table 1. List of planting material

\begin{tabular}{|l|c|c|}
\hline \multicolumn{1}{|c|}{ Seed producer } & Variety & Type \\
\hline \multirow{2}{*}{ Premier Seeds } & 'New Kaduna' & Hybrid \\
\cline { 2 - 3 } & 'Sammaz 27' & Open pollinated \\
\hline \multirow{2}{*}{ Maslaha Seeds } & 'SDM-1' & Hybrid \\
\hline \multirow{2}{*}{ Da-All-Green Seeds } & 'Suwan-1-stry' & Hybrid \\
\cline { 2 - 3 } & 'Jo-195' & Open pollinated \\
\cline { 2 - 3 } & 'Sammaz 15' & Opollinated \\
\hline
\end{tabular}

\section{Seed quality tests}

The seed samples were subjected to standard germination, seedling vigour analysis, accelerated ageing, conductivity and fast green tests. The standard germination test was used to assess the germination potential of the seeds, accelerated ageing test was used to determine the storability and conductivity test was used to access the vigour of the seeds. Fast green method was also used to evaluate the mechanical quality of the seeds. Apart from mechanical quality tests that was carried out after the processing was done, standard germination test, seedling vigour analysis, conductivity, accelerated ageing test and field emergence tests were carried out both before and after seeds were mechanically processed.

\section{Fast green test}

One hundred seeds were soaked in $0.25 \%$ fast green solution for 15 seconds (Ajayi et al., 2006).

The fast green solution was made by completely dissolving $0.25 \mathrm{~g}$ of fast green salt in $100 \mathrm{ml}$ distilled water. At the end of the testing period, the fast green solution was removed while the seeds were rinsed with distilled water. The number of seeds that were stained along the damaged areas and crack lines were counted and expressed in percentage according to the formula:

$$
\text { Level of damage }=\frac{\text { Total number of seeds that are stained }}{\text { Total number of seed soaked }} \times 100
$$

\section{Standard germination test}

One hundred seeds were planted into already wetted river sand media contained in germination plastic trays. The wetted medium was allowed to equilibrate overnight before the seeds were planted. The number of seeds that produced normal seedling was counted on the fourth and seventh day after planting. From the set of data generated, germination percentage $(\% \mathrm{G})$ was calculated using the formula below as suggested by Ajayi and Fakorede (2000). Abnormal and dead seeds were also counted and expressed as a percentage of the total number of seeds sown.

$$
\text { Germination percentage }=\frac{\text { Total number of seedlings that emerged on the final count }}{\text { Total number of seeds planted }} \times 100
$$




\section{Seedling vigour analysis}

Fifty seeds were sown following standard germination test method. As suggested by Ajayi and Fakorede (2000), ten normal seedlings per replicates were harvested on the seventh day after sowing. From the harvested seedlings, shoot length, root length, length of coleoptile, length of mesocotyl and length of the primary leaf were measured with a meter ruler and expressed in centimeter.

\section{Accelerated ageing test}

Fifty seeds from each seed lots replicated three times were aged in an accelerated ageing chamber at 43 ${ }^{\circ} \mathrm{C}$ for $72 \mathrm{~h}$ as described by ISTA (1995). Accelerated ageing germination percentage (AAT), was calculated following the formula for calculating standard germination percentage as suggested by Ajayi and Fakorede (2000).

\section{Bulk conductivity test}

Fifty seeds were randomly selected from the pure seed sample, weighed and placed into $250 \mathrm{ml}$ glass beaker already containing $100 \mathrm{ml}$ of distilled water. The flasks with the content were covered with aluminum foil to prevent contamination and were gently shaken at intervals. Conductivity measurements were taken at $0,30,60,90,120,150,180 \mathrm{~min}$ and finally at $24 \mathrm{~h}$ at $25^{\circ} \mathrm{C}$. The conductivity per gram of seed was expressed in $\mu \mathrm{Scm}^{-1} \mathrm{~g}^{-1}$ and computed as follows (ISTA, 1995):

$$
\text { Conductivity of seed }=\frac{\text { Conductivity }(\mu \mathrm{S}) \text { for each flask }- \text { conductivity of distilled water }}{\text { Dry weight }(\mathrm{g}) \text { of seed sample }}
$$

\section{Field trial and field establishment}

One hundred seeds obtained from the sample were sown per row in three replications. Seeds were sown one plant per stand with a spacing of $0.625 \times 0.175 \mathrm{~m}$ in 4-row plots. The two central Emergence counts were observed within seven days of planting. Data were collected only from the two middle rows. Emergence count was made following standard germination test rules (ISTA, 2007). Field Emergence percentage was calculated following the formula for calculating standard germination percentage as suggested by Ajayi and Fakorede (2000).

$$
\text { Emergence Percentage }=\frac{\text { Total number of seedlings that emerged on the final count }}{\text { Total number of seeds planted }} \times 100
$$

\section{Statistical analyses}

Data collected were subjected to analysis of variance using PROG GLM of SAS (2003). Values in percentage units were transformed using arcsine transformation technique. Means were separated using Least Significant Difference (LSD test, $\mathrm{p}>0.05$ ). Seed electrolyte leachate was regressed against time (min). In order to identify the inflexion points, that is, maximum and minimum points (Clarke, 1970) on the leakage curve and by inference the different stages of electrolyte leakage, difference in the amount of leakage at each measurement point and the preceding one were also plotted against time on the same graph.

\section{Results}

\section{Interrelationship among seed quality tests}

In overall, before the mechanical processing, significant differences $(p>0.05)$ in mean values were observed between the OPVs and hybrid seeds for normal seedling from standard germination test, number of dead seeds, amount of electrolyte leachate after $24 \mathrm{~h}$ of soaking and normal seedlings from accelerated ageing test (Table 2). No significant differences were observed for hundred seed weight, abnormal seedling and percent 
field emergence. For hybrid, it is apparent that mean values for normal seedling from standard germination and accelerated ageing tests were significantly lower $(p>0.05)$ when compared to the mean values for OPVs. But mean values for dead seeds from standard germination test and amount of electrolyte leachate from conductivity test were significantly higher ( $p>0.05$ ) for hybrid when compared to OPVs. After processing, similar trend was observed among the evaluated traits except that the mean values for number of damaged seeds and abnormal seedling after germination test for hybrid were significantly higher when compared to that of OPVs varieties (Table 3).

Table 2. Mean values for quality traits for the seed types before mechanical processing

\begin{tabular}{|l|l|l|l|l|l|c|c|}
\hline \multicolumn{1}{|c|}{ Seed type } & HSWT & GPCT & ABN & DEAD & FEM & COND & AAT \\
\hline Hybrid & $225.36 \mathrm{a}$ & $96.78 \mathrm{~b}$ & $1.00 \mathrm{a}$ & $2.22 \mathrm{a}$ & $93.22 \mathrm{a}$ & $5.77 \mathrm{a}$ & $53.89 \mathrm{~b}$ \\
\hline OPVs & $233.36 \mathrm{a}$ & $98.89 \mathrm{a}$ & $0.78 \mathrm{a}$ & $0.33 \mathrm{~b}$ & $92.22 \mathrm{a}$ & $4.46 \mathrm{~b}$ & $74.33 \mathrm{a}$ \\
\hline
\end{tabular}

Means with different letters in a column are significantly different (LSD test, $\mathrm{p}>0.05$ )

Table 3. Mean values for quality traits for the seed types after mechanical processing

\begin{tabular}{|l|c|c|c|c|c|c|c|c|}
\hline Seed type & HSWT & NDS & GPT & ABN & DEAD & FEM & COND & AAT \\
\hline Hybrid & $225.36 \mathrm{a}$ & $8.78 \mathrm{a}$ & $94.34 \mathrm{~b}$ & $2.22 \mathrm{a}$ & $3.44 \mathrm{a}$ & $92.00 \mathrm{a}$ & $6.84 \mathrm{a}$ & $39.89 \mathrm{~b}$ \\
\hline OPVs & $233.36 \mathrm{a}$ & $3.78 \mathrm{~b}$ & $98.55 \mathrm{a}$ & $0.89 \mathrm{~b}$ & $0.56 \mathrm{~b}$ & $91.22 \mathrm{a}$ & $5.12 \mathrm{~b}$ & $62.56 \mathrm{a}$ \\
\hline
\end{tabular}

Means with different letters in a column are significantly different (LSD test, $\mathrm{p}>0.05$ )

\section{Varietal response to seed quality tests}

Considering varietal performances after the mechanical processing, 'Sammaz 15' consistently had significantly highest mean values for normal seedling from standard germination test, accelerated ageing test and percent field emergence while 'JO-195' and 'New Kaduna' had the least values at p $>0.05$ (Table. 4). For abnormal seedling and amount of electrolyte leachate, 'Sammaz 15' had the least value while 'New Kaduna' had the highest value. For number of damaged seeds, 'Sammaz 15', 'Sammaz 27' and 'Suwan-1-stry' had the least values while 'JO-195' significantly had the highest value. 'Sammaz 27' apparently had the least number of dead seeds from standard germination test while 'New Kaduna' significantly $(\mathrm{p}>0.05)$ had the highest value (Table 4).

Table 4. Mean differences for quality traits for the varieties after mechanical processing

\begin{tabular}{|l|c|c|c|c|c|c|c|c|c|}
\hline Seed type & Variety & HSWT & NDS & GPT & ABN & DEAD & FEM & COND & AAT \\
\hline OPV & $\begin{array}{c}\text { 'Sammaz } \\
15\end{array}$ & $222.87 \mathrm{bc}$ & $4.00 \mathrm{c}$ & $99.00 \mathrm{a}$ & $0.00 \mathrm{c}$ & $1.00 \mathrm{bc}$ & $95.00 \mathrm{a}$ & $4.21 \mathrm{~d}$ & $75.67 \mathrm{a}$ \\
\hline OPV & $\begin{array}{c}\text { 'Sammaz } \\
27\end{array}$ & $210.87 \mathrm{c}$ & $4.67 \mathrm{c}$ & $98.33 \mathrm{ab}$ & $1.67 \mathrm{~b}$ & $0.00 \mathrm{c}$ & $86.33 \mathrm{~d}$ & $5.84 \mathrm{c}$ & $65.00 \mathrm{~b}$ \\
\hline OPV & $\begin{array}{c}\text { 'Suwan-1- } \\
\text { stry' }\end{array}$ & $266.93 \mathrm{a}$ & $2.67 \mathrm{c}$ & $98.33 \mathrm{ab}$ & $1.00 \mathrm{bc}$ & $0.67 \mathrm{bc}$ & $92.33 \mathrm{~b}$ & $5.29 \mathrm{c}$ & $47.00 \mathrm{c}$ \\
\hline Hybrid & 'SDM-1' & $229.33 \mathrm{~b}$ & $9.33 \mathrm{ab}$ & $95.33 \mathrm{bc}$ & $1.33 \mathrm{~b}$ & $3.33 \mathrm{ab}$ & $93.00 \mathrm{~b}$ & $6.15 \mathrm{bc}$ & $34.33 \mathrm{~d}$ \\
\hline Hybrid & 'JO-195' & $229.67 \mathrm{~b}$ & $9.67 \mathrm{a}$ & $93.33 \mathrm{c}$ & $3.67 \mathrm{a}$ & $3.00 \mathrm{ab}$ & $90.00 \mathrm{c}$ & $7.05 \mathrm{ab}$ & $47.00 \mathrm{c}$ \\
\hline
\end{tabular}

Means with different letters in a column are significantly different (LSD test, $\mathrm{p}>0.05$ )

\section{Effect of mechanical damage on seedling vigour}

Seedling traits for aged processed seeds showed a significant decline over the unaged processed ones (Table 5). For both hybrids and OPVs, seedling analysis performed on processed seeds after being subjected to ageing test showed that mean values for all the seedling parts apart from length of mesocotyl were significantly lower when compared with unaged seed (Table 5). However, the impact was more severe on shoot and root length of hybrid seeds than OPVs (Table 6 and 7). 
Table 5. Seedling vigour analysis for hybrid and open pollinated varieties after processing

\begin{tabular}{|c|c|c|c|c|c|c|c|}
\hline Seed type & Treatment & SHL & RTL & NOR & MESOC & LCOEP & LIST \\
\hline \multirow{2}{*}{ Hybrid } & Unaged & $9.11 \mathrm{a}$ & $22.71 \mathrm{a}$ & $4.13 \mathrm{a}$ & $2.39 \mathrm{a}$ & $5.02 \mathrm{a}$ & $7.87 \mathrm{a}$ \\
\cline { 2 - 8 } & Aged & $6.83 \mathrm{~b}$ & $12.39 \mathrm{~b}$ & $3.11 \mathrm{~b}$ & $2.52 \mathrm{a}$ & $2.1 \mathrm{~b}$ & $4.01 \mathrm{~b}$ \\
\hline \multirow{2}{*}{ OPV } & Unaged & $9.60 \mathrm{a}$ & 24.58 & $4.27 \mathrm{a}$ & $2.50 \mathrm{a}$ & $3.52 \mathrm{a}$ & $7.62 \mathrm{a}$ \\
\cline { 2 - 8 } & Aged & $7.77 \mathrm{~b}$ & 18.56 & $3.56 \mathrm{~b}$ & $2.27 \mathrm{a}$ & $2.27 \mathrm{~b}$ & $3.99 \mathrm{~b}$ \\
\hline
\end{tabular}

Means with different letters in a column are significantly different (LSD test, $p>0.05$ )

Table 6. Seedling parameters from standard germination test for hybrid and open pollinated varieties before processed seeds were subjected to accelerated ageing test for $72 \mathrm{~h}$

\begin{tabular}{|l|c|c|c|c|c|c|}
\hline \multicolumn{1}{|c|}{ Variety } & SHL & RLT & NOR & MESCO & LCOEP & LIST \\
\hline 'JO-195' & $9.87 \mathrm{~b}$ & $27.67 \mathrm{a}$ & $4.23 \mathrm{ab}$ & $2.65 \mathrm{~b}$ & $9.13 \mathrm{a}$ & $7.73 \mathrm{~d}$ \\
\hline 'SDM-1' & $7.75 \mathrm{f}$ & $21.45 \mathrm{c}$ & $3.67 \mathrm{~b}$ & $1.80 \mathrm{~d}$ & $2.79 \mathrm{f}$ & $7.99 \mathrm{~b}$ \\
\hline 'New Kaduna' & $9.71 \mathrm{c}$ & $19.00 \mathrm{~d}$ & $4.23 \mathrm{ab}$ & $2.73 \mathrm{~b}$ & $3.16 \mathrm{~d}$ & $7.91 \mathrm{c}$ \\
\hline 'Suwan-1-stry' & $8.83 \mathrm{~d}$ & $24.60 \mathrm{~b}$ & $4.23 \mathrm{ab}$ & $1.29 \mathrm{e}$ & $3.69 \mathrm{c}$ & $7.69 \mathrm{e}$ \\
\hline 'Sammaz 27' & $8.07 \mathrm{e}$ & $25.13 \mathrm{~b}$ & $4.63 \mathrm{a}$ & $2.05 \mathrm{c}$ & $3.05 \mathrm{e}$ & $6.97 \mathrm{f}$ \\
\hline 'Sammaz 15' & $11.91 \mathrm{a}$ & $24.00 \mathrm{~b}$ & $4.33 \mathrm{a}$ & $4.15 \mathrm{a}$ & $3.83 \mathrm{~b}$ & $8.20 \mathrm{a}$ \\
\hline
\end{tabular}

Means with different letters in a column are significantly different (LSD test, $\mathrm{p}>0.05$ )

Table 7. Seedling parameters from standard germination test for hybrid and open pollinated varieties after processed seeds were subjected to accelerated ageing test for $72 \mathrm{~h}$

\begin{tabular}{|l|c|c|c|c|c|c|}
\hline \multicolumn{1}{|c|}{ Variety } & SHL & RLT & NOR & MESCO & LCOEP & LIST \\
\hline 'New Kaduna' & $7.50 \mathrm{ab}$ & $16.30 \mathrm{ab}$ & $3.33 \mathrm{a}$ & $2.60 \mathrm{a}$ & $1.93 \mathrm{ab}$ & $4.47 \mathrm{ab}$ \\
\hline 'JO-195' & $6.67 \mathrm{bc}$ & $9.47 \mathrm{c}$ & $3.00 \mathrm{a}$ & $2.50 \mathrm{a}$ & $2.77 \mathrm{a}$ & $4.67 \mathrm{a}$ \\
\hline 'SDM-1' & $6.33 \mathrm{c}$ & $11.40 \mathrm{bc}$ & $3.67 \mathrm{a}$ & $2.47 \mathrm{a}$ & $1.60 \mathrm{~b}$ & $3.03 \mathrm{ab}$ \\
\hline 'Sammaz 15' & $8.27 \mathrm{a}$ & $18.33 \mathrm{a}$ & $4.33 \mathrm{a}$ & $2.07 \mathrm{a}$ & $2.67 \mathrm{a}$ & $4.50 \mathrm{ab}$ \\
\hline 'Sammaz 27' & $7.70 \mathrm{ab}$ & $18.93 \mathrm{a}$ & $3.00 \mathrm{a}$ & $2.40 \mathrm{a}$ & $2.13 \mathrm{ab}$ & $4.60 \mathrm{a}$ \\
\hline 'Suwan-1-stry' & $7.33 \mathrm{abc}$ & $18.40 \mathrm{a}$ & $3.33 \mathrm{a}$ & $2.33 \mathrm{a}$ & $2.00 \mathrm{ab}$ & $2.87 \mathrm{~b}$ \\
\hline
\end{tabular}

Means with different letters in a column are significantly different (LSD test, $\mathrm{p}>0.05$ )

\section{Relationship between the seed quality parameters and field emergence parameters}

Correlation analysis reveals that germination percentage $(r=0.55)$ and shoot length from aged seedling $(r=0.46)$ had a significant positive correlation with first field emergence count. Number of abnormal seedling $(r=-0.60)$, number of dead seeds $(-0.54)$, root length $(r=-0.64)$, number of damaged seeds in percentage $(r=$ $-0.45)$, conductivity of the seeds $(r=-0.50)$, had negative correlation with the field emergence parameters (Table 8).

\section{The pattern of electrolyte leakage}

The pattern of electrolyte leakage after 180 minutes soaking was noticeably triphasic and each phase ended with an inflexion (Figure 1). Averaged over the six varieties investigated, the first phase of electrolyte leakage was characterized by an initial rapid and progressively increasing rate of leakage. Electrolyte leakage for the first thirty minutes reveals an increase in seed weight as a result of water imbibition. Subsequently in the second phase, the amount of electrolyte leachate progressively decreased from thirtieth minute to the ninetieth minute after the commencement of leakage. In general, the first phase was attained at the thirtieth minute for four of the six varieties, while the second phase was attained at the ninetieth minute (Figure 1). 
Table 8. Correlation analysis for physiological quality (standard germination, accelerated ageing, seedling vigour analysis), number of damage seed in percentage, field emergence traits after seed lots were processed

\begin{tabular}{|l|c|c|c|c|c|c|c|c|c|c|c|c|}
\hline & ISTGPCT & GPCT & ABN & DEAD & SHT & RTL & NDS & COND & AAT & ASHT & ARTL & ISTFEM \\
\hline GPCT & -0.09 & & & & & & & & & & & \\
\hline ABN & 0.32 & $-0.89^{* *}$ & & & & & & & & & & \\
\hline DEAD & $-0.53^{*}$ & -0.39 & 0.05 & & & & & & & & & \\
\hline SHT & -0.44 & 0.29 & -0.38 & -0.06 & & & & & & & & \\
\hline RTL & 0.34 & -0.31 & $0.48^{*}$ & -0.16 & 0.11 & & & & & & & \\
\hline NDS & $-0.52^{*}$ & 0.19 & -0.31 & 0.39 & -0.09 & -0.01 & & & & & & \\
\hline COND & -0.18 & $-0.60^{* *}$ & $0.55^{*}$ & 0.44 & -0.13 & 0.20 & 0.13 & & & & & \\
\hline AAT & 0.37 & 0.35 & -0.12 & -0.70 & $0.53^{*}$ & $0.50^{*}$ & -0.39 & -0.45 & & & & \\
\hline ASHT & 0.23 & 0.27 & -0.10 & $-0.67^{* *}$ & $0.47^{*}$ & -0.05 & $-0.53^{*}$ & -0.32 & 0.65 & & & \\
\hline ARTL & $0.48^{*}$ & -0.12 & 0.30 & $-0.56^{*}$ & 0.06 & 0.08 & $-0.78^{* *}$ & -0.10 & 0.42 & $0.69^{* *}$ & & \\
\hline ISTFEM & 0.29 & $0.55^{*}$ & -0.34 & $-0.54^{*}$ & 0.03 & -0.28 & $-0.45^{*}$ & -0.50 & 0.36 & $0.46^{*}$ & 0.42 & \\
\hline FEM & -0.15 & 0.38 & $-0.60^{*}$ & 0.03 & 0.30 & $-0.64^{*}$ & -0.15 & -0.44 & -0.06 & 0.18 & 0.001 & 0.31 \\
\hline
\end{tabular}

Spearman correlation coefficients, $\mathrm{N}=18,{ }^{*},{ }^{* *}$ and ${ }^{* * *}$ significant at the $p \leq 0.05,0.01$ and 0.001 probability levels, respectively. - = negatively correlated, $+=$ positively correlated
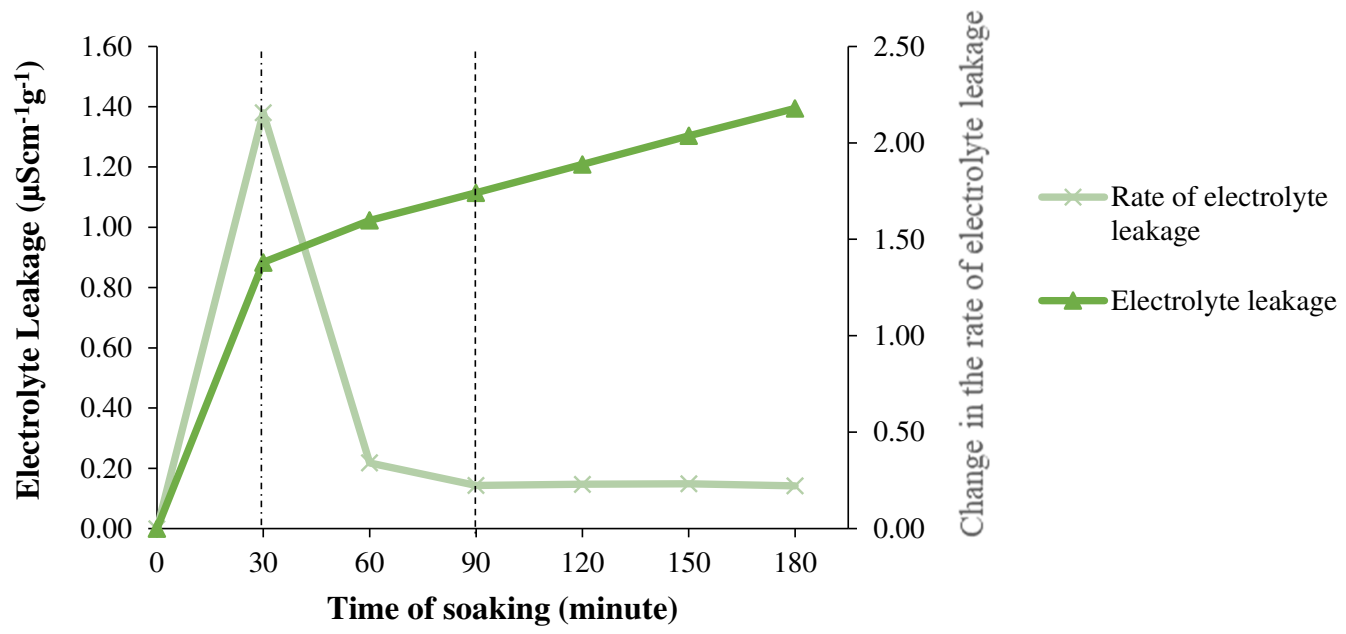

Figure 1. Pattern and stages of electrolyte leakage by intact seeds of maize seeds (each point is the mean of six varieties and 50 seeds per variety)

Dotted line: End of stage I and End of Stage II

Although the pattern was similar for both hybrid and OPVs, there were differences in the magnitude of leachate as well as in what time each seed type (hybrid or OPVs) passed through the two phases (Figure 2). However, among the varieties, 'JO-195' had the highest electrolyte leachate with conductivity measurement of $2.02 \mu \mathrm{Scm}^{-1} \mathrm{~g}^{-1}$ at thirtieth minutes when compared to other seed varieties (Figure 3). 


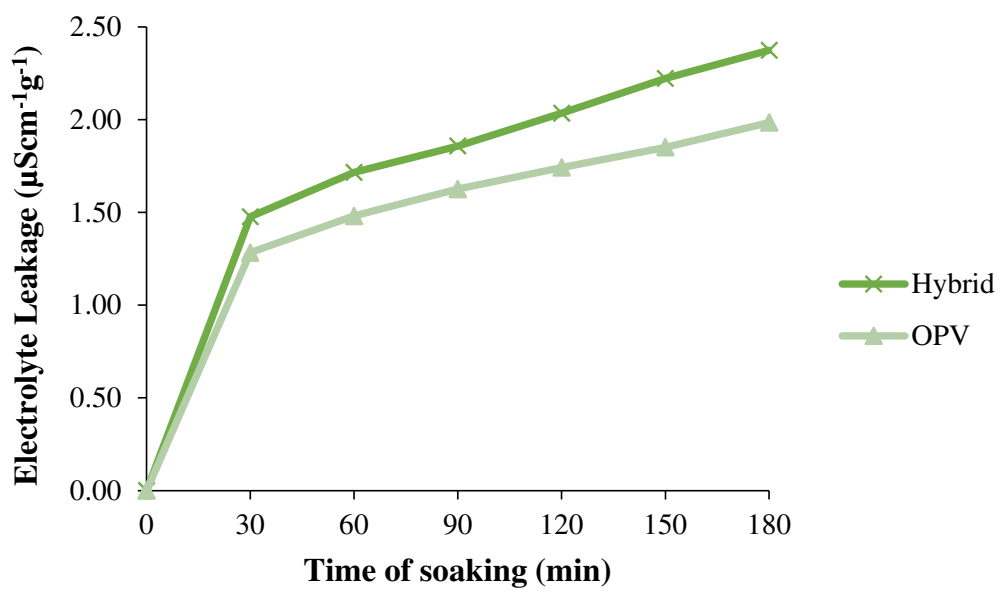

Figure 2. Pattern of electrolyte leakage release during 180 mins of soaking

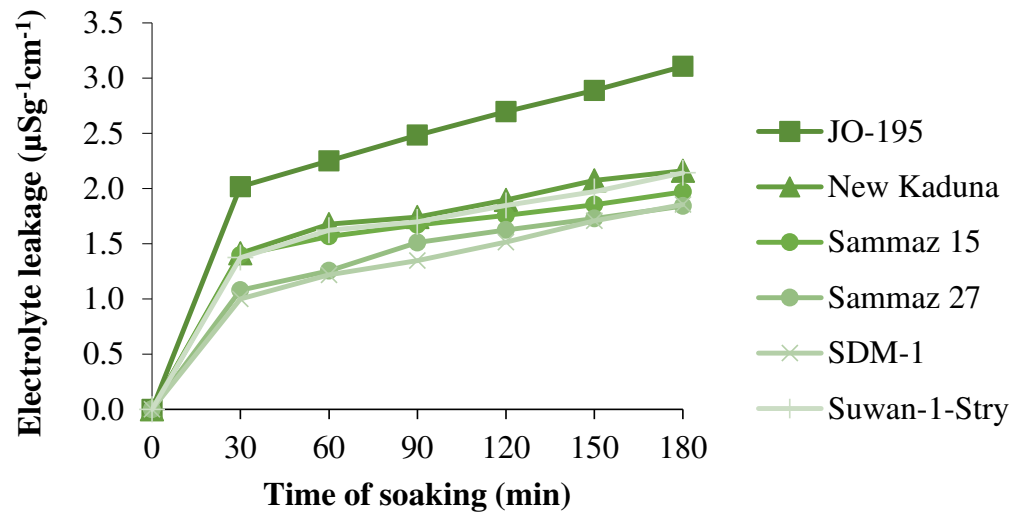

Figure 3. Pattern of electrolyte leakage during 180 minutes of soaking

\section{Discussion}

Mechanical quality refers to resistance to physical damage during mechanical harvesting and postharvest operations (ISTA, 2009) due to accidental impacts (Baryeh, 2002). Such injuries may include seed coat rupture, seed fracture and other physical injuries. Also, physical injuries may occur during seed maturation in the field due to inherent genetic aspects of the varieties. In this term, using the number of damage seeds as an index, OPV seeds were approximately 3 times more resistant to mechanical damage than the hybrid seeds. This is an indication that the genetic identity of the seed lots plays a significant role in determining the mechanical quality of the seed lots (Shahbazi and Shahbazi, 2018). Size of seeds used in this study did not influence the degree of seeds damage partly because grading was excluded from the processing activities (Ajayi et al., 2006).

The impact of mechanical damage on physiological qualities of the seeds showed that mechanical damage affects germination and storage potential negatively. Two percent reduction in germination potential for hybrid seeds after processing was significant enough to cause germination problems when such seeds are faced with stressful condition when introduced into the farmers' field (Olisa et al., 2010). A significant reduction in storage potential of processed seeds by $11 \%$ for OPVs and $14 \%$ for hybrid seeds when compared with unprocessed seeds is an indication that physiological deterioration has occurred. The number of normal seedlings from aged seeds of OPVs was approximately $24 \%$ higher than that of hybrid seeds. This suggests that 
the storability of hybrid seeds is inherently lower than that of OPVs. This explains one of the reasons for low adoption of hybrid seed in commercial seed industries of developing countries as suggested by (Pixley and Bänziger, 2001). Thus, accelerated ageing test could be used to discriminate between damaged seeds and undamaged ones for mechanical damage assessment.

Seedling vigour of aged seeds was significantly affected by mechanical damage for both hybrids and OPVs. Damage to embryo often results into abnormal formation of the seedling parts (ISTA, 2007; Seedcheck, 2020). Shoot and root length of both seed types were more affected than other seedling parts. Reduction in shoot and root length recorded in this study is an indication that the meristematic cells of the embryonic axis are severely affected suggesting that the damage is physiological in nature. This explains the occurrence of poor seedling root establishment when seed lots were planted on the field. Obviously, reduced shoot and root lengths are good indicators of exposure of seed to physiological stress from ageing process (Hussein et al., 2012) or salinity (Sozharajan and Natarajan, 2014). That the length of mesocotyl remains unchanged for aged when compared to unaged seeds of both seed types indicates that the deterioration due to damage and ageing processes has not progressively reached the mesocotyl region. This could partly explain the inefficiency of visual identification of mechanical damage to detect a measurable damage on the embryo itself while the covering layers were affected (Brauggink et al., 1991). However, such embryonic damage is not detected until the seeds are germinated resulting into poor seedling establishment. This is because roots directly absorb water from the soil while shoot supplies water to other plant parts (Jamil and Raha, 2004). Generally, after germination, seedling establishment and growth are characterized by morphological and physiological elongation of coleoptile followed by elongation of the first leaf and radicle which culminates into growth of the embryonic axis. Coleoptile and first leaf form the plumule which is the growing point of the shoot, while coleorhiza and radicle form the growing point of the root (Arteca, 1995). Reduction in the root length and coleoptile from aged hybrid seeds by approximately half signifies that the damaged hybrid seeds when planted will have uneven emergence and poor seedling establishment. Therefore, changes to shoot and root structure provide an important hint that can be used to monitor the response of plants to stress as suggested by Sozharajan and Natarajan (2014). Thus, the assessment of mechanical damage using combination of accelerated ageing test and seedling vigour analysis could be used to discriminate between damaged and undamaged maize seeds.

As seeds imbibe water during the early stage of germination, there is rapid leakage of electrolyte leachate into the surrounding medium. The rate of leakage during this period shows that there are differences among the experimental varieties in relation to resistance to mechanical damage (Brauggink et al., 1991; Ouyang et al., 2002). Higher electrolyte leachate recorded for processed seeds when compared to unprocessed ones suggests that conductivity test can be used to monitor mechanical quality of maize seed lots along the production value chain as suggested by Ouyang et al. (2002). Similarly, electrolyte leachate from processed hybrid seeds was higher than the OPVs counterpart, which suggested that hybrid seeds are associated with low vigour (Powell, 2009). Among other indices, electrical conductivity test is used to assess seed vigour in relation to seed performance (Pandey, 1992; Powell, 2006). The test measures the leakage of solutes into water. And an increase in the electrical conductivity of seed soak water indicates high solute leakage. Loss of solutes from seeds reveals loss of integrity of cell membranes and/or the presence of dead tissues within the seed on one hand and loss of seed vigour on the other hand (Powell, 2006). According to Brauggink et al. (1991) different parts of maize kernel could be affected differently during mechanical processing. Damage to pericarp often results into rapid electrolyte leakage within the first two hours of imbibition while damage to endosperm caused higher leakage than damage at the embryo. This damage to endosperm and embryo occurs after a prolonged time of soaking although at lesser rate. Severe damage to endosperm involves pericarp and underlying tissues, whereas damage at the embryo probably often restricted to the covering layers, without the embryo itself being damaged. Contrary to this observation, this study showed that for both unprocessed and processed seeds, reduction in shoot and root length after seedling vigour analysis is as a result of damaged embryonic axis. The discrepancies between these reports probably were as a result of difficulty of visual identification of mechanical damage as claimed by Loeffler et al. (1988). However, the damage was higher for processed aged seeds than the 
unprocessed counterpart. Therefore, the resultant increased leakage reported for both unprocessed and processed seeds could not have been related to mechanical damage alone but probably include the combination of ageing and imbibition damage (Brauggink et al., 1991).

\section{Conclusions}

All varieties from hybrid group have more damaged seeds than varieties from OPV groups. For all the traits assessed across the experimental varieties, 'Sammaz 15' is more resistant to mechanical damage while 'JO195 ' is the most susceptible. Shoot length and root length were more affected than other parts of the seedling. The pattern of electrolyte leakage during 180 minutes soaking was triphasic and each phase ended with an inflexion. There were differences in the magnitude of electrolyte leakage as well as in what time each seed type (hybrid or OPVs) passed through the phases with 'JO-195' having the highest rate of electrolyte leakage. In overall, 'Sammaz 15', the best among OPVs, was more promising when compared with SDM-1 which was the best among hybrid varieties. Hybrid seed has lower resistance to mechanical damage and subsequently storability when compared with OPVs. Future research should be directed towards elucidating seed structure, biochemical factors and gene expression as they affect mechanical qualities of hybrids and OPVs.

\section{Authors' Contributions}

Conceptualization BS; Field surveys BS, NJ and CU; Data curation BS, FE and MS; Formal analysis BS and FE; Funding acquisition, Project administration, Resources, Software \& Supervision BS, PO and KO; Writing - original draft BS; Writing - review and editing FE, MS and A. All authors read and approved the final manuscript.

\section{Acknowledgements}

This research received no specific grant from any funding agency in the public, commercial, or not-forprofit sectors.

\section{Conflict of Interests}

The authors declare that there are no conflicts of interest related to this article.

\section{References}

Ajayi SA, Fakorede MAB (2000). Physiological maturity effects on seed quality, seedling vigour and mature plant characteristics of maize in a tropical environment. Seed Science and Technology 28:301-319.

Ajayi SA, Gerhard RL, Jörg MG (2006). Impact of mechanical damage to hybrid maize seed from harvesting and conditioning. Seed Technology 28:7-21.

Arteca RN (1995). Seed germination and seedling growth. In: Arteca RN (Ed). Plant Growth Substances. New York, Chapman and Hall Press, pp 105-126.

Badu-Apraku B, Asuboah RA, Fakorede B, Asafo-Adjei B (2014). Strategies for sustainable maize seed production in West and Central Africa. IITA, Nigeria. Retrieved 2020 April 3 from https://www.researchgate.net/publication/267228983 
Baryeh EA (2002). A simple grain impact damage assessment device for developing countries.

Journal of Food Engineering 56:37-42. https://doi.org/10.1016/s0260-8774(02)00145-0

Bassett C (2019). The Breed of your seed: Understanding the difference between open-pollinated, hybrid, Heirloom and GMO. NOFA/Massachusetts Newsletter, February Issue. Retrieved 2020 April 20 from https://www.nofamass.org/articles/2019/02/breed-your-seed-understanding-difference-between-openpollinated-hybid-heirloom

Desai BB (2004). Seed Handbook. Processing and Storage. Retrieved 2017 January 27 from http://books.google.com/books?isbn=082474800X

Hussein HJ, Shaheed AI, Yasser OM (2012). Effect of accelerated aging on vigor of local maize seeds in term of electrical conductivity and relative growth rate (RGR). Iraqi Journal of Science 53(2):285-291.

ISTA (1995) Handbook of Vigour Test Methods. In: Hampton JH, TeKrony D (Eds). International Seed Testing Association, Bassersdorf, Switzerland.

ISTA (2007). The Germination Test. International Seed Testing Association, Bassersdorf, Switzerland.

ISTA (2009). International Seed Testing Association. Handbook on seedling evaluation (3rd ed) with amendment. Bassersdorf, Switzerland.

Jamil M, Rha ES (2004). The effect of salinity $(\mathrm{NaCl})$ on the germination and seedling of

sugar beet (Beta vulgaris L.) and cabbage (Brassica oleracea L.). Korean Journal of Plant Research 7:226-232.

Kumawat R, Choudhary M, Kumawat KR (2017). Seed processing and grading. Retrieved on 2021 November 15 from https://www.biotecharticles.com/Agriculture-

Olisa BS, Ajayi SA, Akande SR (2010). Physiological quality of seeds of promising African yam bean (Sphenostylst stenocarpa (Hochst. Ex A. Rich) and pigeon pea (Cajanus cajan L. Mill sp.) landrace. Research Journal of Seed Science 3(2):93-101. https://doi.org/10.3923/rjss.2010.93.101

Pandey DK (1992). Conductivity testing. In: Linskens HF, Jackson JF (Eds). Seed analysis. Berlin Heidelberg New York, Springer-Verlag, pp 273-303.

Pixley K, Bänziger M (2001). Open-pollinated maize varieties: A backward step or valuable option for farmers? Seventh Eastern and Southern Africa Regional Maize 11th - 15th February, 2001 Conference, pp 22-28.

Powell AA (2006). Seed vigour and its assessment. In: Basra AS (Ed). Handbook of Seed Science and Technology. New York, The Haworth Press, Inc., pp 603-647.

SAS Institute (2003). SAS procedure guides, version 9.1 Cary, SAS Institute Inc.

Seed Check (2020). Germination. Retrieved 2020 March 12 from https://www.seedcheck.net/seed-checktests/germination/

Shahbazi F, Shahbazi F (2018). Mechanical damage to corn seeds. Cercetări Agronomice în Moldova 51(3/175):1-12.

Sozharajan R, Natarajan S (2014). Germination and seedling growth of Zea mays L. under different levels of sodium chloride stress. International Letters of Natural Sciences 12:5-15. https://doi.org/10.18052/www.scipress.com/ILNS.12.5

Umar UA, Muhammad MB, Aliyu AS (2014). Maize production and yield improvement in Nigeria (1994-2013). Retrieved 2017 August 12 from www.share4dev.info/fmard/documents/5243.pdf
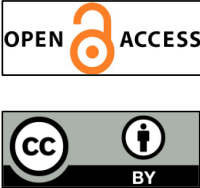

The journal offers free, immediate, and unrestricted access to peer-reviewed research and scholarly work. Users are allowed to read, download, copy, distribute, print, search, or link to the full texts of the articles, or use them for any other lawful purpose, without asking prior permission from the publisher or the author.

License - Articles published in Notulae Scientia Biologicae are Open-Access, distributed under the terms and conditions of the Creative Commons Attribution (CC BY 4.0) License.

(c) Articles by the authors; SHST, Cluj-Napoca, Romania. The journal allows the author(s) to hold the copyright/to retain publishing rights without restriction. 